\title{
Pengaruh Kompetensi Leadership Guru Pendidikan Agama Islam Terhadap Perkembangan Moral Siswa SMK Terpadu Ad-Dimyati Kota Bandung
}

\author{
Ulfah $^{1}$, Rina Susandra ${ }^{2}$ \\ 1,2 Universitas Islam Nusantara Bandung \\ E-mail: ulfahpai@uninus.ac.id
}

\section{Article Info \\ Article History \\ Received: 2021-09-21 \\ Revised: 2021-10-28 \\ Published: 2021-11-09}

Keywords:

Competencies;

Leadership

PAI Teachers:

Moral Development.

\begin{abstract}
The approach in this study is a quantitative approach with descriptive statistical research methods. This research was conducted at the ad-Dimyati Integrated Vocational School, Bandung City with a total population of 161 students who are students of class XI. While the sample in this study as many as 48 people by taking $30 \%$ of the population. The results obtained are PAI teacher leadership competencies are in the very good category, because they are in the 3.00 - 4.00 interval, while the students' moral development results are in the very good category, because they are in the 3.00 4.00 interval. From the calculation results obtained 5,238 and Sig. $=0.027<0.05$, which means that $\mathrm{H} 0$ is rejected and $\mathrm{H} 1$ is accepted or the significance is smaller than the specified error level. Thus, the $\mathrm{Y}$ on $\mathrm{X}$ regression is significant or it can be stated that the PAI teacher's leadership competence has an effect on the moral development of students at the Ad-Dimyati Integrated Vocational School, Bandung City. The value of $\mathrm{R}$ Square in the determinant correlation test is 0.102 or it can be interpreted that only $10.2 \%$ of students' moral development in Ad-Dimyati Integrated Vocational School can be explained by using the variable influence of PAI teacher leadership competence on students' moral development at Ad-Dimyati Terpadu Vocational School. While the remaining $89.8 \%(100 \%-10.2 \%)$ must be explained by other influencing factors.
\end{abstract}

\begin{tabular}{l}
\hline Artikel Info \\
\hline Sejarah Artikel \\
Diterima: 2021-09-21 \\
Direvisi: 2021-10-28 \\
Dipublikasi: 2021-11-09
\end{tabular}

Kata kunci:

Kompetensi;

Kepemimpinan;

Guru PAI;

Pengembangan moral.

\section{Abstrak}

Pendekatan dalam penelitian ini yaitu pendekatan kuantitatif dengan metode penelitian statistik deskriptif. Penelitian ini dilaksanakan di SMK Terpadu ad-Dimyati Kota Bandung dengan jumlah populasi sebanyak 161 siswa yang merupakan siswa kelas XI. Sedangkan sampel dalam penelitian ini sebanyak 48 orang dengan mengambil $30 \%$ dari populasi. Hasil yang di peroleh yaitu kompetensi leadership guru PAI berada pada kategori sangat baik, karena ada pada interval 3,00 - 4,00, sedangkan hasil perkembangan moral siswa berada pada kategori sangat baik, karena ada pada interval $3,00-4,00$. Dari hasil perhitungan diperoleh 5,238 dan Sig. $=0,027<0,05$ yang artinya $\mathrm{H} 0$ ditolak dan $\mathrm{H} 1$ diterima atau signifikasi lebih kecil dari taraf kesalahan yang ditentukan. Dengan demikian, regresi $Y$ atas $X$ adalah signifikan atau dapat di nyatakan bahwa kompetensi leadership guru PAI berpengaruh terhadap perkembangan moral Siswa di SMK Terpadu Ad-Dimyati Kota Bandung. Nilai R Square pada uji korelasi determinan sebesar 0,102 atau dapat di artikan bahwa hanya 10,2\% perkembangan moral siswa di SMK Terpadu Ad-Dimyati dapat dijelaskan dengan menggunakan variabel pengaruh kompetensi leadership guru PAI terhadap perkembangan moral siswa di SMK Terpadi Ad-Dimyati. Sedangkan sisanya 89,8\% (100\% - 10,2\%) harus dijelaskan oleh faktor-faktor pengaruh lain.

\section{PENDAHULUAN}

Dalam kehidupan bermasyarakat yang dinamis, pendidikan memegang peranan yang sangat menentukan eksistensi dan perkembangan kelompok masyarakat. Hal ini menurut (Irwansyah, 2021) karena pada hakikatnya pendidikan merupakan bagian yang tidak dapat dipisahkan dari hidup dan kehidupan manusia, Menurut Undang-Undang No. 20 tahun 2003 tentang SISDIKNAS Bab I mengatakan, pendidikan adalah usaha sadar dan terencana untuk mewujudkan suasan belajar dan proses pembelajaran agar peserta didik secara aktif mengembangkan potensi dirinya untuk memiliki kekuatan spiritual keagamaan, pengendalian diri, kepribadian, kecerdasan, akhlak mulia, serta keterampilan yang diperlukan bagi dirinya, masyarakat, bangsa dan Negara, definisi tersebut merupakan perumusan pendidikan yang paling baik dan sempurna serta menjadi acuan di Indonesia. Selanjutnya, menurut (Arifudin, 2021) pendidikan Islam di Indonesia sudah berlang- 
sung sejak masuknya Islam ke Indonesia, yang mana menurut catatan sejarah Islam masuk ke Indonesia dengan cara damai yaitu dengan jalur perdagangan. Dengan melihat kegiatan pendidikan Islam di Indonesia sampai saat ini, pendidikan Islam sudah banyak berkontribusi dalam mewujudkan cita-cita luhur bangsa Indonesia sebagaimana terkandung dalam teks UUD 1945 alinea ke-4 yaitu "Mencedaskan Kehidupan Bangsa". Selain itu, pendidikan Islam di Indonesia telah menunjukkan dinamika perkembangan pendididikan Islam itu sendiri dengan masuknya pendidikan Islam dalam sistem pendidikan nasional.

Pendidikan Islam mempunyai tujuan membentuk insan kamil. Muhaimin dalam (Hasbi, 2021) mengungkapkan bahwa insan kamil yaitu manusia yang memiliki wajah Qur'ani, tercapainya insan yang memiliki dimensi religius, budaya dan ilmiah. Hal tersebut juga merupakan suatu hal yang berkaitan dengan fungsi khalifah yang di tugaskan oleh Allah SWT kepada manusia yang mana dengan di anugerahkannya akal fikiran kepada manusia untuk berfikir. Sebagaimana dalam firman-Nya yang artinya: Ingatlah ketika Tuhanmu berfirman kepada para Malaikat: "Sesungguhnya Aku hendak menjadikan seorang khalifah di muka bumi". Mereka berkata: "Mengapa Engkau hendak menjadikan (khalifah) di bumi itu orang yang akan membuat kerusakan padanya dan menumpahkan darah, padahal kami senantiasa bertasbih dengan memuji Engkau dan mensucikan Engkau?" Tuhan berfirman: "Sesungguhnya Aku mengetahui apa yang tidak kamu ketahui".

Berdasarkan QS. Al-Baqarah ayat 30 diatas, dapat ketahui bahwa untuk mencapai tujuan tersebut maka di perlukan komponen-komponen pandidikan dalam pelaksanannya. Menurut (Nadeak, 2020) bahwa salah satu dari komponen penting dalam pendidikan yaitu guru yang berperan sebagai Transformator of Knowladge, dimana tugasnya yaitu sebagai orang yang menyalurkan atau mentransfer segala keilmuan kepada siswa, adapun menurut Undang-Undang Sistem Pendidikan Nasional tahun 2003 Bab I Pasal 1 Point 5 dan 6, pendidik adalah tenaga kependidikan yang berkualifikasi sebagai Guru, Dosen, konselor, pamong belajar, widya iswara, tutor, instruktur, fasilitator, dan sebutan lain yang sesuai dengan kekhususannya serta berpartisipasi dalam penyelenggaraan pendidikan.

Sebagai seorang pendidik, Guru Pendidikan Agama Islam (PAI) juga harus memiliki kompe- tensi-kompetensi dasar yang seharusnya dimiliki oleh seorang guru. Menurut Keputusan Menteri Agama (KMA) No. 211 tahun 2011 yang melengakapi Permendiknas No. 16 tahun 2007 tentang standar kualifikasi akademik dan kompetensi guru, guru wajib memiliki kompetensi yang meliputi kompetensi pedagogik, kepribadian, sosial, dan profesional yang diperoleh melalui pendidikan profesi, menurut Ramayulis dalam (Tanjung, 2020) mengemukakan bahwa kompetensi pedagogik merupakan kemampuan guru dalam pengelolaan pemeblajaran peserta didik. Kompetensi kepribadian adalah kompetensi yang berhubungan dengan pengembangan kepriba-dian sebagai seorang pendidik (guru). Kompe-tensi sosial merupakan kompetensi yang berhubungan dengan kemampuan guru sebagai bagian dari anggota masyarakat. Sedangkan, kompetensi profesional adalah kompetensi atau kemapuan yang berhubungan dengan keahlian yang dimilikinya.

Selain keempat kompetensi dasar guru diatas, guru Pendidikan Agama Islam juga diharapkan mampu menjadi pelopor yang mampun berperan melakukan pengembangan kehidupan beragama di sekolah dan lingkungan sosialnya. Oleh sebab itu, dalam Peraturan Menteri Agama Republik Indonesia Nomor 16 Tahun 2010 Tentang Pengelolaan Pendidikan Agama Pada Sekolah Pasal 16, guru Pendidikan Agama harus memiliki kompetensi tambahan yaitu kompetensi kepemimpinan, sebagaimana tercantum dalam Permenag nomor 16 tahun 2010 ayat (1) guru PAI diharuskan memiliki kompetensi tambahan, yaitu kompetensi leadership (kepemimpinan). Kompetensi kepemimpinan sebagaimana dimaksud pada bab IV ayat (1)-(6) meliputi:

1. Kemampuan membuat perencanaan pembudayaan pengamalan ajaran agama dan perilaku akhlak mulia pada komunitas sekolah sebagai bagian dari proses pembelajaran agama

2. Kemampuan mengorganisasikan potensi unsur sekolah secara sistematis untuk mendukung pembudayaan pengamalan ajaran agama pada komunitas sekolah

3. Kemampuan menjadi inovator, motivator, fasilitator, pembimbing dan konselor dalam pembudayaan pengamalan ajaran agama pada komunitas sekolah

4. Kemampuan menjaga, mengendalikan, dan mengarahkan pembudayaan pengamalan ajaran agama pada komunitas sekolah dan menjaga keharmonisan hubungan antar 
pemeluk agama dalam bingkai Negara Kesatuan Republik Indonesia.

Berdasarkan penjelasan mengenai kompetensi leadership di atas dapat di pahami bahwa kompetensi leadership ini merupakan suatu hal yang penting dan harus dimiliki oleh seorang guru PAI. Menurut (Nasser, 2021) bahwa selain harus berperan sebagai seorang guru yang harus menjadi teladan dan memberikan contoh yang baik dari segala sisi kepada anak didik, guru PAI juga dianggap sebagai ujung tombak dimana guru PAI juga diharapkan mampu menjadi pelopor yang mampu berperan melakukan pengembangan kehidupan beragama di sekolah yang menjujung nilai-nilai Islami. Dalam hal ini yaitu diutamakan pada perkembangan moral siswa, dimana guru PAI dianggap menjadi penanggung jawab utama dari penanaman moral di sekolah.

Moral pada dasarnya merupakan rangkaian nilai tentang berbagai macam perilaku yang harus dipatuhi. Nilai-nilai moral hendaknya dijunjung tinggi oleh kelompok sosial masyarakat, sehingga dapat mencetak generasi yang bermoral. Maka dari itu, menurut (Arifudin, 2020) bahwa perkembangan moral dapat diartikan sebagai perkembangan yang berkaitan dengan kemampuan seseorang untuk mengetahui baik dan buruk suatu perbuatan, kesadaran untuk berbuat baik, dan rasa cinta terhadap perbuatan baik, adapun teori perkembangan moral yang popular yaitu yang di ungkapkan oleh Kohlberg dalam (Siregar, 2021), menurutnya tahapan perkembangan moral terbagi menjadi 3 (tiga) tingkat yaitu tingkat prakonvensional, konvensional, dan pascakonvensional.

Tahapan perkembangan moral yang pertama yaitu tingkat prakonvensional yaitu memperhatikan ketaatan, hukum, dan pemuasan kebutuhan. Kedua yaitu tingkat konvensional yang memperhatikan citra anak baik, hukum dan peraturan. Ketiga, tingkat pascakonvensional yaitu memperhatikan hak perseorangan dan prinsip-prinsip etika. Berdasarkan tahapantahapan perkembangan moral tersebut, menurut Muhibbin Syah dalam (Tanjung, 2021) bahwa tingkat penalaran moral remaja berada pada tahap pascakonvensional dimana seorang remaja jika dibandingkan dengan anak-anak maka tingkat moralitas remaja sudah lebih matang. Seorang remaja sudah mulai mengenal bagaimana konsep-konsep moralitas seperti, kejujuran, keadilan, kesopanan, kedisiplinan dan mengartikan perilaku baik sebagai hak pribadi sesuai dengan aturan dan patokan sosial. Riset menyatakan bahwa prinsip-prinsip tersebut menggambarkan keyakinan yang sebenarnya dari pemikiran moral pascakonvensional, dalam berkomunikasi juga sangat memegang peranan penting dalam menentukan moral anak sehingga sesuai dengan kondisinya dan memahami berbagai aturan yang berlaku di sekolah, akan tetapi, saat ini pendidikan nasional sedang dihadapkan pada masalah degradasi moral, berbagai macam perilaku yang menyimpang sudah banyak dilakukan oleh remaja pelajar yang hakikatnya adalah sebagai penerus bangsa ini. Sebagai contoh, beberapa perilaku menyimpang yang baru-baru ini terjadi di kalangan remaja yang di kutip (Sofyan, 2020a) yaitu seperti:

1. Viral Remaja Nekat Hentikan Truk, Ini Penyebabnya Kata Psikolog. Video empat remaja mencegat truk agar berhenti mendadak di perempatan Sentul, Bogor, viral di media sosial. Tragisnya, satu di antara remaja tersebut terlindas truk tersebut. Aksi berbahaya seperti ini bukan yang pertama. Sebelumnya sudah banyak kejadian serupa yang dilakukan remaja. Bahkan ada yang melakukannya demi konten.

2. Sambil Acungkan Senjata Tajam, Puluhan Remaja di Kota Serang Blokade Jalan. Bunyi geberan gas sepeda motor meraung-raung di Kota Serang, Banten. Malam itu, puluhan remaja terlihat memblokade Jalan Ahmad Yani. Tak hanya bunyi bising knalpot yang bikin pengguna jalan lainnya resah. Sambil berteriak, para remaja itu mengacungkan senjata tajam. Mereka membawa celurit, pedang, dan golok bergerigi.

3. Kelompok Remaja di Jakarta Barat, Aksi Tawuran Biar Viral. Sekelompok remaja melakukan aksi tawuran di Kota Bambu Utara, Palmerah, Jakarta Barat. Mirisnya, para pelaku melakukan aksi tawuran itu agar terkenal di media sosial. Aksi tawuran itu viral di media sosial. Kompol Supriyanto mengatakan peristiwa itu terjadi pada Minggu (30/8) dini hari.

Beberapa perilaku menyimpang di atas merupakan sebagian kecil dari degredasi moral remaja yang terjadi saat ini. Masih banyak sekali kejadian perilaku menyimpang yang di lakukan oleh remaja seperti tidak menghormati orang yang lebih tua, tawuran antar remaja pelajar, minum minuman keras, vandalisme, penyalahgunaan narkoba, bullying, seks bebas, lesbian gay biseksual dan transgender (LGBT), berkata kasar, dan lain-lain, beberapa contoh perilaku menyimpang tersebut merupakan sebagian kecil dari macam-macam bentuk dari masalah 
degradasi moral yang terjadi saat ini, perilakuperilaku menyimpang inilah yang menjadi gambaran dari menurunnya moral remaja saat ini yang tidak dapat dielakan lagi, degradasi moral ini tentunya tidak muncul tanpa sebab, adapun menurut (Bairizki, 2021) bahwa faktorfaktor yang menyebabkan degradasi moral yaitu seperti masuknya budaya barat di lingkungan sekitar, kurangnya perhatian dan kasih sayang dari orang tua, proses sosialisasi yang kurang sempurna serta rendahnya tingkat pendidikan, dan lain sebagainya.

Berdasarkan hasil penelitian yang di lakukan oleh Repositori Riset Kesehatan Nasional di wilayah Jawa Barat dan Bali tentang kenakalan remaja dengan jumlah responden 1.100 remaja di Jawa Barat (Bandung dan Cianjur) dan 877 remaja di Provinsi Bali (Denpasar dan Gianyar), hasil yang di dapatkan yaitu bahwa umur ratarata remaja yang mulai melakukan kenakalan tersebut antara 15-19 tahun. Beberapa faktor yang melatar belakangi kenakalan remaja antara lain adalah disharmoni keluarga, gangguan fungsi sekolah, sakit hati, pelampiasan kekesalan, solidaritas kawan dan ketidakpuasan remaja.

Berdasarkan pemaparan hasil penelitian di atas dapat di lihat bahwa permasalahan degradasi moral remaja bukanlah permasalahan yang dapat dianggap enteng, melainkan ini merupakan permasalahan yang serius. Moral remaja dinegeri ini sudah sangat mengkhawatirkan, hal ini tentunya tidak dapat dibiarkan begitu saja, tindakan yang serius juga harus segera dilakukan dalam menangani masalah ini. Terlebih, peran guru Pendidikan Agama Islam yang selama ini sering menjadi "suspect" (tersangka) dalam permasalahan degradasi moral anak didiknya, hal inilah yang di rasakan oleh guru Pendidikan Agama Islam di SMK Terpadu Ad-Dimyati yaitu dalam permasalahan, seolah guru PAI-lah yang menjadi penanggung jawab tunggal dalam permasalahan moral siswanya. Pertanyaan-pertanyaan menohok seperti pertanyaan siapa dan bagaimana guru PAI mengajarkan tentang adab dan perilaku kepada siswanya sering kali dilontarkan oleh kebanyakan masyarakat apabila ada seorang anak yang melakukan perbuatan tidak baik. Melalui pertanyaan-pertanyaan tersebut membuktikan bahwa persepsi masyarakan terhadap moral siswa ialah tanggung jawab guru PAI di sekolah. Padahal jika di tinjau kembali, sebagaimana dijelaskan diatas bahwa perkembangan moral seseorang dapat di pengaruhi oleh beberapa faktor seperti keluarga dan juga lingkungan sosialnya supaya tidak terusmenerus di jadikan suspect utama dalam permasalahan degradasi moral remaja saat ini tentunya peran aktif dari guru PAI yang berkompeten sangat dibutuhkan. Sebagai contoh yaitu dengan melakukan pembiasaan perilaku dan kegiatan positif yang sesuai dengan ajaran Agama Islam yang digagas dan dibimbing oleh guru PAI. Dengan adanya pembiasaan melakukan hal-hal yang positif di sekolah, maka diharapkan peserta didik akan terbiasa melakukan kegiatan yang positif dan kemudian ditularkan ke lingkungan sosialnya.

Guru PAI dituntut untuk memiliki kompetensi lebih dibandingkan dengan guru mata pelajaran lain, yaitu kompetensi leadership. Kompetensi ini menurut (Arifudin, 2018) merupakan indikator yang ada pada seorang yang dikatakan memiliki kelebihan. Dalam hal ini berarti guru Pendidikan Agama Islam memiliki amanah menjadi seorang pemimpin di sekolah, dengan kata lain guru PAI menjadi komando yang senantiasa menyerukan kebaikan kepada siswanya agar mereka menjadi generasi yang memiliki moral baik. Oleh karenanya, kompetensi leadership ini menjadi salah satu kompetensi yang harus dimiliki oleh guru PAI untuk mengatasi permasalahan degredasi moral remaja yang terjadi saat ini.

Berdasarkan pemaparan di atas, peneliti tertarik untuk melalukan kajian yang akan dituangkan dalam penelitian yang berjudul "Pengaruh Kompetensi Leadership Guru Pendidikan Agama Islam Terhadap Perkembangan Moral Siswa SMK Terpadu Ad-Dimyati Kota Bandung".

\section{METODE PENELITIAN}

Pendekatan penelitian yang digunakan dalam penelitian ini yaitu pendekatan kuantitatif. Menurut (Rahayu, 2020) bahwa penelitian Kuantitatif adalah kegiatan pengumpulan, pengolahan, analisis dan penyajian data berdasarkan jumlah atau banyaknya yang dilakukan secara objektif untuk memecahkan suatu persoalan atau menguji suatu hipotesis untuk mengembangkan prinsip-prinsip umum, Penelitian kuantitatif menurut (Ulfah, 2021) adalah penelitian yang banyak menuntut penggunaan angka, mulai dai pengumpulan data, penafsiran terhadap data tersebut, serta penampilan dari hasilnya. Demikian pula pada tahap kesimpulan penelitian akan lebih baik bila disetai dengan gambar, tabel, grafik datau tampilan lainnya. 
Penelitian dengan menggunakan pendekatan kuantitatif menurut (Labetubun, 2021) bertujuan untuk menganalisis, dan mendeskripsikan fenomena yang ada menggunakan angka-angka. Penelitian ini tentunya terfokus untuk memperoleh data dari kedua variabel yaitu kompetensi leadership guru Pendidikan Agama Islam (X) dan perkembangan moral siswa $(\mathrm{Y})$ yang merupakan data numerik dari hasil angket yang ditunjukkan kepada responden, dan selanjutnya dianalisis dengan menggunakan analisis statistik untuk mendapatkan kesimpulan, Kuesioner atau angket menurut (Sofyan, 2020b) bahwa merupakan teknik pengumpulan data yang dilakukan dengan member seperangkat pertanyaan atau pernyataan tertulis kepada responden untuk dijawabnya. Pada penelitian ini penulis menyebarkan angket kepada responden yang merupakan siswa kelas XI SMK Terpadu Ad-Dimyati Kota Bandung yang berjumlah 48 siswa sebagai sampel dari populasi, Penelitian ini dilaksanakan di SMK Terpadu ad-Dimyati Kota Bandung dengan jumlah populasi sebanyak 161 siswa yang merupakan siswa kelas XI. Sedangkan sampel dalam penelitian ini sebanyak 48 orang dengan mengambil $30 \%$ dari populasi.

\section{HASIL DAN PEMBAHASAN}

\section{A. Kompetesi Leadership Guru Pendidikan Agama Islam di SMK Terpadu Ad-Dimyati Kota Bandung}

Seorang guru PAI mempunyai tanggung jawab lebih, dimana tanggung jawab tersebut tidak di miliki oleh guru lain. Disamping harus berperan sebagai guru yang bertanggungjawab mentransfer ilmu pengetahuan kepada siswa, guru PAI juga di tuntunt untuk berperan sebagai pemimpin, agar dapat menjalankan tanggung jawab tersebut tentunya guru PAI juga harus memiliki kompetensi tambahan, yaitu kompetensi leadership, sebagaimana tercantum dalam Permenag nomor 16 tahun 2010 ayat (1) Kompetensi kepemimpinan sebagaimana dimaksud pada bab IV ayat (1)-(6) meliputi:

a. Kemampuan membuat perencanaan pembudayaan pengamalan ajaran agama dan perilaku akhlak mulia pada komunitas sekolah sebagai bagian dari proses pembelajaran agama

b. Kemampuan mengorganisasikan potensi unsur sekolah secara sistematis untuk mendukung pembudayaan pengamalan ajaran agama pada komunitas sekolah c. Kemampuan menjadi inovator, motivator, fasilitator, pembimbing dan konselor dalam pembudayaan pengamalan ajaran agama pada komunitas sekolah

d. Kemampuan menjaga, mengendalikan, dan mengarahkan pembudayaan pengamalan ajaran agama pada komunitas sekolah dan menjaga keharmonisan hubungan antar pemeluk agama dalam bingkai Negara Kesatuan Republik Indonesia.

Berdasarkan hasil penelitian, kompetensi leadership guru PAI di SMK Terpadu AdDimyati kota Bandung masuk dalam kategori sangat baik karena guru PAI di nilai telah memenuhi seluruh aspek-aspek dari indikator kompetensi leadership guru PAI yaitu sebagai berikut:

a. Guru mampu merencanakan kegiatankegiatan keagamaan sebagai bentuk pengamalan materi belajar seperti mengajak seluruh siswa untuk berdo'a dan membaca al-Qur'an sebelum memulai aktivitas, memimpin pengajian rutin dan dzikir bersama setiap pekan, mengajak warga sekolah untuk membuat perencanaan kegiatan keagamaan dalam menyambut hari-hari besar Islam dan berperan aktif membimbing panitia kegiatan keagamaan hari besar Islam.

b. Guru mampu menentukan sarana dan prasaran yang menunjang dalam pelaksanaan pengamalan pengajaran ajaran agama Islam yaitu seperti menyediakan Al-Qur'an dalam pelaksanaan bimbingan membaca Al-Qur'an dan menggunakan masjid dalam setiap kegiatan keagamaan.

c. Guru mampu melibatkan seluruh warga sekolah untuk berpartisipasi dalam pelaksanaan pembudayaan pengamalan ajaran agama Islam yaitu dengan mengajak siswa untuk saling bekerjasama dalam setiap pelaksanaan kegiatan yang diadakan disekolah dan meminta peserta didik bergegas ke masjid ketika masuk waktu sholat dan menghentikan proses pembelajaran sejenak ketika suara Adzan berkumandang.

d. Guru mampu menyebarluaskan ide-ide baru yang berupa ilmu pengetahuan dan teknologi yaitu di tunjukkan dngan membawakan materi pelajaran dengan menggunakan metode yang tepat dan media yang menarik agar mudah untuk di fahami oleh siswa. 
e. Guru mampu menjadi motivator bagi setiap warga sekolah yaitu dengan memberi motivasi serta dukungan kepada siswa untuk senantiasa berperilaku terpuji baik di lingkungan sekolah maupun di lingkungan masyarakat.

f. Guru mampu menjadi fasilitator yaitu dengan menyediakan fasilitas untuk pengembangan potensi siswa.

g. Guru mampu menjadi pembimbing dan konselor bagi seluruh warga sekolah yang dapat di lakukan dengan cara menerima dengan senang hati dan memberikan jalan keluar apabila siswa ingin berkonsultasi mengenai permasalahan yang sedang dihadapi.

h. Guru mampu menjaga dan mengendalikan pembudayaan pengamalan ajaran agama pada komunitas sekolah yaitu dengan mengawasi setiap kegiatan yang di lakukan oleh siswa baik di dalam kelas maupun kegiatan di luar kelas, dan menegur siswa yang melangguran aturan dan tata tertib yang berlaku di sekolah.

i. Guru mampu mengarahkan pembudayaan pengamalan ajaran agama pada komunitas sekolah seperti mengarahkan organisasi siswa untuk senantiasa melaksanakan program-program yang positif.

Berdasarkan pada hasil rata-rata (mean) data setiap item angket didapatkan nilai mean $>3,00$. Hal ini menunjukkan bahwa rata-rata siswa menilai guru PAI di SMK Terpadu AdDimyati kota Bandung memiliki kompetensi leadership yang termasuk dalam kualifikasi sangat baik. Kompetensi leadership guru PAI tentunya di pengaruhi oleh beberapa faktor, sebagaimana di ungkapkan oleh Bahrun menyebutkan bahwa ada beberapa faktor yang mempengaruhi kompetensi leadership guru, yaitu sebagai berikut:

a. Supervisi pendidikan, yaitu melakukan pembinaan secara terus menerus yang telah dirancang untuk membantu guru dalam melakukan pekerjaan.

b. Pendidikan dan pelatihan, yaitu suatu cara untuk mengembangkan mutu atau kualitas dari guru dengan proses dan metode agar tercapai hasil yang diinginkan. Pendidikan dan pelatihan dilakukan melalui intervise training dengan tujuan untuk mencapai mutu pengetahuan, pengalaman dan kecakapan guru. c. Pemberian motivasi, yaitu dilakukan untuk mendorong dan mengubah energi positif dalam meningkatkan kompetensi guru.

Hal inilah yang di lakukan oleh guru PAI di SMK Terpadu Ad-Dimyati Kota Bandung. Dengan latar belakang pendidikan Strata 1 Pendidikan Agam Islam, dan pengabdiannya sebagai seorang guru selama 15 tahun tidak pernah berhenti untuk selalu memperbarui keilmuannya, dengan mengikuti seminarseminar dan juga dan pelatihan-pelatihan seperti IHT (In House Training) untuk awal tahun ajaran baru, pelatihan BLK untuk ketua Jurusan, pelatihan untuk Bimbingan Koseling (BK), pelatihan bimbingan karir, save the childrend, dan pelatihan-pelatihan yang lainnya.

\section{B. Perkembangan Moral Siswa di SMK Terpadu Ad-Dimyati Kota Bandung}

Perkembangan moral yaitu perkembangan yang berkaitan dengan kemampuan seseorang untuk mengetahui baik dan buruk suatu perbuatan, kesadaran untuk berbuat baik, dan rasa cinta terhadap perbuatan baik. adapun tingkatan perkem-bangan moral menurut Kohlberg yaitu sebagai berikut:

a. Tingkat Prakonvensional Pada tingkat ini, anak tanggap terhadap aturan-aturan budaya dan ungkapan-ungkapan budaya mengenai baik dan buruk serta benar dan salah. Namun demikian, semua ini masih ditafsirkan dari segi akibat fisik atau kenikmatan perbuatan (hukuman, keuntungan, pertukaran kebaikan) atau dari segi kekuatan fisik mereka yang memaklumkan peraturan. Tingkat prakonvensional ini memiliki dua tahap, yaitu orientasi hukuman dan kepatuhan serta orientasi relativis-instrumental.

b. Tingkat Konvensional Pada tingkat ini anak hanya menuruti harapan keluarga, kelompok, atau masyarakat. Semua itu dipandang sebagai hal yang bernilai dalam dirinya sendiri tanpa mengindahkan akibat yang bakal muncul. Sikap anak bukan saja konformitas terhadap pribadi dan tata teltib sosial, melainkan juga loyal terhadapnya dan secara aktif mempertahankan, mendukung, dan membenarkan seluruh tata tertib, serta mengidentifikasikan diri dengan orang atau kelompok yang terlibat. Tingkat konvensional ini memiliki dua tahap, yaitu orientasi kesepakatan antara pribadi atau disebut 
orientasi "anak manis" serta orientasi hukum dan ketertiban.

c. Tingkat Pascakonvensional, Otonom, atau Berlandaskan Prinsip Pada tingkatan usaha yang jelas untuk merumuskan nilai-nilai dan prinsip moral yang memiliki keabsahan dan dapat diterapkan, terlepas dari otoritas kelompok atau orang yang berpegang pada prinsip-prinsip itu dan terlepas pula dari identifikasi diri dengan kelompok tersebut. Tingkat ini memiliki dua tahap, yaitu orientasi kontrak sosial legalitas serta orientasi prinsip dan etika universal.

Berdasarkan pemaparan hasil angket mengenai perkembangan moral siswa di atas, dapat disimpulkan bahwa rata-rata (mean) data setiap item di dapatkan nilai mean $>3,00$ yang berarti hasil data tentang perkembangan moral siswa di SMK Terpadu Ad-Dimyati Kota Bandung termasuk dalam kategori "sangat baik" karena dari 21 pernyataan yang di ajukan kepada responden rata-rata berada pada interval 3,00-4,00. Maka dapat di simpulkan bahwa bahwa siswa SMK Terpadu Ad-Dimyati Kota Bandung berada pada tingkat Pascakonvensional, berdasarkan hasil penelitian sebagain besar siswa menjawab sangat setuju pada pertnyataan nomor 16-21 yang merupakan indikator dari aspek tingkat penalaran Pasca-Konvensional yaitu:

a. Mampu memahami bahwa perbuatan baik cenderung dirumuskan dengan kerangka hak

b. Mampu memiliki kesadaran yang jelas mengenai relativisme pada nilai-nilai, pendapat pribadi, dan tekanan pada prosedur untuk mencapai kesepakatan

c. Mampu mengembangkan suatu standar moral berdasarkan hak-hak manusia universal

d. Mampu memahami bahwa perbuatan yang benar yaitu sesuai dengan suara hati yang mengacu pada pandangan logis

e. Mampu menghormati martabat manusia sebagai individual.

Perkembangan moral siswa SMK Terpadu Ad-Dimyati Kota Bandung yang pesat ini di pengaruhi oleh lingkungan sekolah yang agamis, karena pada dasarnya sekolah tersebut ada di bawah naungan Yayasan Pondok Pesantren Sirnamiskin sebagai bentuk pengembangan Pendidikan di Pesantren
Sirnamiskin yang didirikan pada tahun 1935 oleh KH. Achmad Dimyati.

SMK Terpadu Ad-Dimyati Kota Bandung lebih menitik beratkan pada pendidikan agama Islam dimana selain mengenyam pendidikan formal siswa juga di ajarkan ilmu agama sebagaimana pendidikan yang di lakukan pesantren, maka dari itu moral siswa dapat terlihat jelas dari sopan santun dan budi pekerti yang di tampilkan oleh para siswa saat penulis melakukan penelitian ini. Hal ini tentunya selaras dengan visi dan misi SMK Terpadu Ad-Dimyati Kota Bandung, adapun visi dan misinya yaitu sebagai berikut:

a. Visi Sekolah Terciptanya siswa yang Berilmu Amaliah, Beramal Ilmiah, Bertaqwa Illahiyah, Berakhlaqul Karimah dan Berdaya saing di dunia kerja/industri serta berjiwa wirausaha.

b. Misi Sekolah

1) Terciptanya sekolah unggulan model dan terdepan dalam mewujudkan kader bangsa yang memiliki kualitas imtaq dan iptek serta memiliki sikap sebagai warga negara yang baik dan bertanggung jawab.

2) Terciptanya suasana sekolah yang kondusif bagi terselnggaranya proses pembelajaran yang bermutu dengan dukungan berbagai fasilitas yang memadai dan tenaga pendidik yang ahli dan bertanggung jawab.

3) Terciptanya siswa yang berorientasi pada keilmuan, kecerdasan, kesholehan, kemandirian dan ketaqwaan.

4) Menyiapkan siswa agar mampu berkiprah di masyarakat, diterima di dunia usaha/ industri serta mampu berwirausaha dan melanjutkan pendidikan ke jenjang yang lebih tinggi.

\section{Pengaruh Kompetesi Leadership Guru Pendidikan Agama Islam terhadap Perkembangan Moral Siswa di SMK Terpadu Ad-Dimyati Kota Bandung}

Berdasarkan hasil uji regresi yang telah di lakukan, dapat diketahui bahwa pada tabel coefisien dalam kolom constant a adalah 16,400 dan pada kolom b 0,840 sehingga persamaan regresinya yaitu: $\hat{Y}=a+b X$ atau $16,400+0,840 \mathrm{X}$, maksudnya yaitu konstanta sebesar 16,400 menyatakan bahwa jika tidak ada nilai kompetensi leadership guru Pendidikan Agama Islam maka nilai perkembangan moral siswa sebesar 16,400 
dan koefisien regresi $X$ sebesar 0,840 menyatakan bahwa setiap penambahan 1 nilai kompetensi leadership guru Pendidikan Agama Islam maka nilai perkembangan moral siswa bertambah sebesar 0,840.

Berdasarkan pada perhitungan di atas dapat disimpulkan bahwa nilai t_hitung adalah 2,289 dengan nilai signifikansi 0,027 < 0,05, maka H0 ditolak dan Ha diterima artinya terdapat pengaruh signifikan antara competensi leadership guru Pendidikan Agama Islam (Variabel X) terhadap perkembangan moral siswa di SMK Terpadu Ad-Dimyati Kota Bandung (Variabel Y).

Untuk mengetahui besarnya pengaruh independen (kompetensi leadership guru PAI) terhadap dependen (perkembangan moral siswa), maka penulis menguraikan analisis bagian ringkasan model menunjukan besarnya koefisien determinasi yang berfungsi untuk mengetahui besarnya variabilitas variabel dependen perkembangan moral siswa yang dapat diterangkan dengan menggunakan variabel independen kompetensi leadership guru PAI. Koefisien determinan juga digunakan untuk menghitung besarnya kontribusi atau pengaruh variabel independen terhadap variabel dependen. Koefisien determinasi dihitung dengan cara mengalikan $\mathrm{R}^{2}$ dengan $100 \%\left(\mathrm{R}^{2}\right.$ x $\left.100 \%\right)$. Nilai penting dalam pengeluaran ini ialah: nilai R Square, nilai Standar Error of the Estimate, dan nilai Durbin-Waston. Nilai R Square dalam tabel 4.51 ialah sebesar 0,102, angka R Square tersebut juga sebagai Koefisien determinasi, 0,102 atau sama dengan 10,2\%. Angka tersebut berarti bahwa sebesar 10,2\% perkembangan moral siswa di SMK Terpadu Ad-Dimyati dapat dijelaskan dengan menggunakan variabel pengaruh kompetensi leadership guru PAI terhadap perkembangan moral siswa di SMK Terpadi Ad-Dimyati. Sedangkan sisanya $89,8 \%(100 \%-10,2 \%)$ harus dijelaskan oleh faktor-faktor penyebab lainnya. Dengan kata lain besarnya pengaruh kompetensi leadership guru PAI terhadap perkembangan moral siswa di SMK Terpadi Ad-Dimyati $10,2 \%$ sedangkan sisanya sebesar $89,8 \%$ dipengaruhi faktor lain diluar model regresi.

Berdasarkan hasil penelitian ini menunjukkan bahwa guru PAI bukanlah satu-satunya yang bertanggung jawab terhadap moral siswanya karena selain faktor kompetensi leadership guru PAI tentunya masih banyak faktor yang dapat mempengaruhi baik atau buruknya moral seseorang. Sebagaimana telah di paparkan sebelumnya, bahwa faktor yang mempengaruhi perkembangan moral yaitu faktor pengalaman belajar di sekolah, faktor keluarga dan faktor lingkungan masyarakatnya. Mengingat dari keseluruhan waktu selama 24 jam, siswa berada di sekolah hanya sekitar 5-6 jam dalam sehari. Maka untuk menyempurnakan moral siswa supaya menjadi manusia yang bermoral tinggi harus ada kerjasama antara pihak guru di sekolah, kondisi keluarga dan juga lingkungan masyarakat sekitar.

Dengan keterbatasan waktu yang di miliki oleh guru untuk berperan aktif membimbing perkembangan moral siswa ke arah yang positif tentunya perlu dilakukan upaya-upaya yang sangat keras. Di sinilah kompetensi leadership guru PAI sangat di butuhkan, karena peran guru PAI sangatlah di butuhkan untuk menciptakan lingkungan sekolah yang agamis dengan cara membudayakan ajaran Islam di lingkungan sekolah melalui memberikan pengalaman pembelajaran agama Islam baik di dalam maupun di luar kelas. Maka, guru PAI juga harus melakukan upaya untuk meningkatkan kompetensi leadership-nya. Adapun upaya-upaya yang perlu di lakukan oleh guru PAI untuk mengingkatkan meningkatkan kompetensi leadership yaitu sebagai berikut:

a. Mempunyai visi atau daya pandang yang mendalam tentang mutu pembelajaran pendidikan agama Islam dan mempunyai komitmen yamg jelas pada proses peningkatan kualitas pembelajaran.

b. Mengomunikasikan materi pendidikan agama Islam sesuai dengan kebutuhan dan karakteristik peserta didiknya.

c. Senantiasa mengembangkan kompetensi diri dan tidak menyalahkan pihak lain jika ada masalah yang muncul tanpa dilandasi bukti yang kuat.

d. Senantiasa melakukan inovasi terhadap pembelajarannya.

e. Mengembangkan komitmen untuk mencoba menghilangkan setiap hambatan dan penghalang, baik bersifat organisasional maupun budaya.

f. Membangun tim kerja yang efektif baik sesama guru, tenaga kependidikan, maupun bersama peserta didik dalam pembelajaran. 
g. Mengembangkan mekanisme yang sesuai untuk melakukan monitoring dan evaluasi.

\section{SIMPULAN DAN SARAN}

\section{A. Simpulan}

Berdasarkan hasil analisis statistik yang dilakukan mengenai pengaruh kompetensi leadership guru Pendidikan Agama Islam terhadap perkembangan moral siswa di SMK Terpadu Ad-Dimyati Kota Bandung dapat dikatakan baik, karena mampu memperbaiki perkembangan moral siswa. Adapun kesimpulan dari analisis yang di lakukan yaitu sebagai berikut:

1. Berdasarkan hasil penelitian mengenai Kompetensi leadership guru Pendidikan Agama Islam masuk dalam kategori sangat baik karena berada pada interval 3,00 4,00. Merujuk pada hasil rata-rata (mean) data setiap item angket didapatkan nilai meadn $>3,00$. Hal ini menunjukkan bahwa rata-rata siswa menilai guru PAI di SMK Terpadu Ad-Dimyati kota Bandung memiliki kompetensi leadership yang termasuk dalam kualifikasi sangat baik.

2. Berdasarkan hasil penelitian tentang Perkembangan moral siswa di SMK Terpadu Ad-Dimyati Kota Bandung bahwa rata-rata (mean) data setiap item di dapatkan nilai mean $>3,00$ yang berarti hasil data tentang perkembangan moral siswa di SMK Terpadu Ad-Dimyati Kota Bandung termasuk dalam kategori "sangat baik" karena dari 21 pernyataan yang di ajukan kepada responden rata-rata berada pada interval 3,00-4,00. Hal ini menunjukkan bahwa siswa SMK Terpadu Ad-Dimyati Kota Bandung berada pada tingkat Pascakonvensional.

3. Berdasarkan uji regresi pada hasil penelitian mengenai Pengaruh Kompetensi leadership guru Pendidikan Agama Islam terhadap Perkembangan moral siswa di SMK Terpadu Ad-Dimyati Kota Bandung dapat di ketahui bahwa dapat diketahui bahwa konstanta sebesar 16,400 menyatakan bahwa jika tidak ada nilai kompetensi leadership guru Pendidikan Agama Islam maka nilai perkembangan moral siswa sebesar 16,400 dan koefisien regresi X sebesar 0,840 menyatakan bahwa setiap penambahan 1 nilai kompetensi leadership guru Pendidikan Agama Islam maka nilai perkembangan moral siswa bertambah sebesar 0,840. Maka dapat disimpulkan bahwa nilai t_hitung adalah 2,289 dengan nilai signifikansi 0,027< 0,05, maka H0 ditolak dan Ha diterima artinya terdapat pengaruh signifikan antara kompetensi leadership guru Pendidikan Agama Islam (Variabel $\mathrm{X}$ ) terhadap perkembangan moral siswa di SMK Terpadu Ad-Dimyati Kota Bandung (Variabel Y). Nilai R Square sebesar 0,102, angka $\mathrm{R}$ Square tersebut juga sebagai Koefisie-n determinasi, 0,102 atau sama dengan 10,2\%. Angka tersebut berarti bahwa sebesar 10,2\% perkembangan moral siswa di SMK Terpadu Ad-Dimyati dapat dijelaskan dengan menggunakan variabel pengaruh kompetensi leadership guru PAI terhadap perkembangan moral siswa di SMK Terpadi Ad-Dimyati. Sedangkan sisanya 89,8\% (100\% - 10,2\%) harus dijelaskan oleh faktor-faktor penyebab lainnya. Dengan kata lain besarnya pengaruh kompetensi leadership guru PAI terhadap perkembangan moral siswa di SMK Terpadi Ad-Dimyati 10,2\% sedangkan sisanya sebesar $89,8 \%$ dipengaruhi faktor lain diluar model regresi.

\section{B. Saran}

Berdasarkan penelitian yang telah dilakukan, maka penulis memberikan saran sebagai berikut:

1. Kompetensi leadership merupakan kompetensi yang harus di miliki oleh guru PAI, maka hendaknya guru senantiasa optimis dan selalu berusaha untuk melakukan upaya-upaya untuk mengatasi degradasi moral pada generasi muda, di mulai dari siswa siswi di SMK Terpadu AdDimyati kota Bandung.

2. Melalui penelitian ini, penulis menyarankan kepada guru PAI khususnya di sekolah SMK Terpadu Ad-Dimyati agar tetap melakukan upaya untuk meningkatkan kompetensi leadership supaya dapat membudayakan ajaran Islam di lingkungan sekolah, sehingga seluruh warga sekolah menjadi manusia yang bermoral dan berakhlaq mulia sesuai dengan aqidah agam Islam.

\section{REFERENCES}

Arifudin, O. (2018). Pengaruh Pelatihan Dan Motivasi Terhadap Produktivitas Kerja Tenaga Kependidikan STIT Rakeyan 
Santang Karawang. MEA (Manajemen, Ekonomi, \& Akuntansi), 2(3), 209-218.

Arifudin, O. (2020). Psikologi Pendidikan (Tinjauan Teori Dan Praktis). Bandung: Widina Bhakti Persada.

Arifudin, O. (2021). Media Pembelajaran Pendidikan Anak Usia Dini. Bandung: Widina Bhakti Persada.

Asmedy. (2018). Pengembangan Perangkat Pembelajaran Bangun Datar dengan Pendekatan Open Ended. JIIP - Jurnal Ilmiah Ilmu Pendidikan, 1(2), 66-72. Retrieved from http://jiip.stkipyapisdompu.ac.id/jiip/index.php/ IIIP/article/view/11

Asmedy. (2020). Perbandingan Hasil Belajar Connected Mathematics Project (CMP) dengan Pembelajaran Konvensional Pada Pokok Bahasan Geometri. JIIP - Jurnal Ilmiah Ilmu Pendidikan,3(1), 456-464. Retrieved from http://jiip.stkipyapisdompu.ac.id/jiip/inde x.php/IIIP/article/view/131

Bairizki, A. (2021). Manajemen Perubahan. Bandung: Widina Bhakti Persada.

Hasbi, I. (2021). Administrasi Pendidikan (Tinjauan Teori Dan Praktik). Bandung: Widina Bhakti Persada.

Irwansyah, R. (2021). Perkembangan Peserta Didik. Bandung : Widina Bhakti Persada.

Labetubun, M. A. H. (2021). Sistem Ekonomi Indonesia. Bandung: Widina Bhakti Persada.
Nadeak, B. (2020). Manajemen Humas Pada Lembaga Pendidikan. Bandung: Widina Bhakti Persada.

Nasser, A. A. (2021). Sistem Penerimaan Siswa Baru Berbasis Web Dalam Meningkatkan Mutu Siswa Di Era Pandemi. Biormatika: Jurnal Ilmiah Fakultas Keguruan Dan Ilmu Pendidikan, 7(1), 100-109.

Rahayu, Y. N. (2020). Program Linier (Teori Dan Aplikasi). Bandung : Widina Bhakti Persada.

Siregar, R. T. (2021). Komunikasi Organisasi. Bandung: Widina Bhakti Persada.

Sofyan, Y. (2020). Peranan Konseling Dosen Wali Dalam Meningkatkan Motivasi Belajar Mahasiswa Di Perguruan Tinggi Swasta Wilayah LLDIKTI IV. Jurnal Bimbingan Dan Konseling Islam, 10(2), 237-242.

Sofyan, Y. (2020). Studi Kelayakan Bisnis Telur Asin H-Organik. Jurnal Ecodemica, 4(2), 341-352.

Tanjung, R. (2020). Pengaruh Penilaian Diri Dan Efikasi Diri Terhadap Kepuasan Kerja Serta Implikasinya Terhadap Kinerja Guru. Jurnal Ilmiah MEA (Manajemen, Ekonomi, Dan Akuntansi), 4(1), 380-391.

Tanjung, R. (2021). Kompetensi Manajerial Kepala Sekolah Dalam Meningkatkan Kinerja Guru Sekolah Dasar. JIIP-Jurnal Ilmiah Ilmu Pendidikan, 4(4), 291-296.

Ulfah. (2021). Manajemen PAUD Berdaya Saing Untuk Meningkatkan Mutu Pendidikan. Edumaspul: Jurnal Pendidikan, 5(1), 385397. 